\title{
No forjar das possibilidades: a "Krupp" Campo Limpo Paulista nos caminhos de trabalhadores (Segunda metade do séc. XX e início do séc. XXI)*
}

\begin{abstract}
Resumo
Este artigo apresenta ponderações sobre a trajetória de trabalhadores que vivenciaram o espaço de trabalho na ThyssenKrupp - Campo Limpo Paulista -, a partir de meados do século XX. O interesse é discutir o repertório de possibilidades de certos trabalhadores, analisando contradições e diferenciações nas memórias que guardam sobre relações de trabalho, associadas às condições de classe que compartilhavam, envolvendo relações entre campo e cidade, como também o processo de expansão industrial. Ao fazer isso, a proposta coloca em questão a suposta vivência homogeneizante do "ser metalúrgico" e a construção analítica fundamentada nas alterações estruturais na dinâmica do mundo do trabalho. As presentes reflexões tentam evidenciar as desigualdades e pressões que potencializam as práticas dos trabalhadores na sociedade capitalista e, ao mesmo tempo, destacam a exploração sofrida e como interpretam as relações e caminhos que decidem enfrentar.
\end{abstract}

Palavras-chave: Trabalhadores. Trajetórias. Relações de trabalho. ThyssenKrupp.

\author{
Sheille Soares de Freitas \\ Doutora em História pela \\ Universidade Federal de \\ Uberlândia. Professora da \\ Universidade Estadual do Oeste \\ do Paraná. \\ sfsheille@gmail.com
}

\begin{abstract}
Para citar este artigo:
FREITAS, Sheille Soares de. No forjar das possibilidades: a "Krupp" Campo Limpo Paulista nos caminhos de trabalhadores (Segunda metade do séc. XX e início do séc. XXI). Revista Tempo e Argumento, Florianópolis, v. 5, n.9, jan./jun. 2013. p. 153 - 187.
\end{abstract}

\section{DOI: $10.5965 / 2175180305092013153$}

http://dx.doi.org/10.5965/2175180305092013153 


\title{
In forging the possibilities: the "Krupp" Campo Limpo Paulista in the paths of workers (Second half of the 2oth century and early 21th century)
}

\begin{abstract}
This article presents ponderations on trajectory of workers who have experienced the workspace in ThyssenKrupp-Campo Limpo Paulista, from the half of the 2oth century. The interest was to discuss the range of possibilities some workers, analyzing contradictions and differentiations in the memories they produce on labor relations, associated with the class condition who they share, involving relations between country and city, as well as the process of industrial expansion. In doing so, the proposal calls into question the supposed homogenizing experience of "being metallurgical" and the analytical construction based on structural alterations in the work world dinamics. The reflections produced they attempt to highlight the inequalities and pressures that emphasize the practices of workers in capitalist society and, at the same time, they highlight the exploration who live and how they interpret the relations and paths who decide cope.
\end{abstract}

Keywords: Workers. Trajectories. Labor relations. ThyssenKrupp. 
Ao pensar estratégias e interpretações sobre as relações classistas a partir da segunda metade do século XX, determinadas relações que envolveram trabalhadores e a empresa ThyssenKrupp Metalúrgica Campo Limpo favoreceram a reflexão sobre os sentidos atribuídos a tais processos de trabalho e à construção de alternativas pelos trabalhadores:

\section{Pesquisador: Como é que o sr. entrou na Krupp?}

Cláudio: Ah, foi em 62. Eu entrei... [...] Entrei foi um amigo... foi quase um amigo que ajudo eu [...] falecido. Ele falô assim: "Tem um rapaz que tá desempregado" [...] Tinha nascido o menino, aí, eu fiquei 4 mês parado. Ai ele... [...] quer dizer, tipo... encaixou, né? Ajudô eu. ${ }^{1}$

A fala de Cláudio indica como este, ou outro posto de trabalho, fazia-se urgente e incerto em 1962. Se, por um lado, o entendimento de que estava "desempregado [...] tinha nascido o menino [...] 4 mês parado" traduzia pressões, este universo de situações também recolocava o embate por melhorias salariais e condições de trabalho, tendo em vista sua condição de desempregado, precisando de ajuda para se inserir em novas empresas.

Esta contraditória relação com o trabalho, expressa ao longo da entrevista, aponta tanto a necessidade de sobrevivência que o levou à Krupp ${ }^{2}$, como as intervenções produzidas em correlações de forças desiguais que o fizeram sair da $\mathrm{Sifco}^{3}$ (emprego anterior), ao se desentender com a chefia na tentativa de mudanças de cargo e salário e se ver desempregado havia quatro meses.

\footnotetext{
${ }^{1}$ Cláudio (pseudônimo). Entrevista realizada por Rinaldo J. Varussa. Jundiaí, 27 de dezembro de 2008. Agradeço à socialização das entrevistas no Grupo de Pesquisa História Social do Trabalho e da Cidade (UNIOESTE), durante a realização do projeto interinstitucional "Nada enraíza num lugar só". Todas as entrevistas utilizadas no texto compõem o conjunto de fontes produzidas durante esse projeto.

${ }^{2}$ A instalação da planta da Krupp em Campo Limpo, então distrito de Jundiaí-SP, em 1957, e inaugurada em 1961, fortaleceu interesses de emancipação do distrito que, três anos após o início das atividades da Krupp, pressionou pela constituição do município de Campo Limpo, atual Campo Limpo Paulista. A fusão dos grupos Krupp e Thyssen se oficializou no final da década de 1990, entre 1998 e 1999, formando o grupo ThyssenKrupp, o qual possui extensões complementares na nomenclatura, conforme especificidade de produção e aquisição de empresa, ou, ainda, de acordo com a visibilidade proposta no mercado internacional. Para este trabalho, o uso do termo Krupp irá prevalecer por ser essa denominação utilizada pelos entrevistados, independente dos marcos de fusão e alteração na nomenclatura da empresa.

${ }^{3}$ Empresa de forjados que atende ao mercado automobilístico desde 1958. Seu Cláudio trabalhou na Sifco em Jundiaí-SP.
} 
As pausas que compõem este trecho da entrevista sugerem em que termos se dão as solidariedades entre os trabalhadores (exposição das condições de vida; pedir intervenção a seu favor; indicar aproximação com valores que legitimem tal ajuda; apelo à condição de provedor da família). Modos de reconhecer que essas pressões são compartilhadas, mas necessitam de sentidos que produzam identificações nas relações firmadas ao longo de um percurso em que se compartilharam valores e, neste caso, se chancelou a amizade "de bar, de clube [...] de tomar pinga né?".

Cláudio é um trabalhador aposentado, que avalia, no momento da entrevista, sua trajetória como positiva, principalmente ao ressaltar sua ascensão de mecânico a "mestre geral” na Krupp. O que lhe permitiu ressaltar o "Ajudô eu” sem demérito próprio. Ele considerou que correspondeu às expectativas dessa ajuda - tanto em relação à empresa quanto às suas próprias -, ainda que os custos dos resultados e sua extensão mereçam ponderações pela dinâmica contraditória que apresentam, como, por exemplo, em relação a problemas de saúde, excesso de trabalho e pouco tempo livre para pensar outras alternativas de trabalho e sociabilidade.

A proposição de Cláudio sugere retirar a possível centralidade da Krupp da entrevista e colocar a produção de sua vida em primeiro plano. Esta memória dá elementos para problematizar alguns pontos intrínsecos ao universo de interesses e práticas dos trabalhadores.

Por isso, mesmo com a indagação sobre a trajetória na Krupp, o que o trabalhador enfatiza é um percurso muito mais amplo do que a data de sua ficha de admissão e as tarefas que exercia e exerceu até se aposentar. Ele formula sua avaliação sobre decisões de trabalho enquanto encaminhamentos com que buscava transformar sua condição de classe.

Os 50 anos de existência da Krupp, em Campo Limpo Paulista/SP, permitem indagar sobre o lugar que ela ocupa nas relações de classe, que acentuam a experiência de trabalhadores que se valem dessa relação para enfrentar problemas comuns na sociedade capitalista contemporânea - moradia, sustento da família, problemas de saúde, profissionalização, etc. 
A elaboração comemorativa, enunciada no site da empresa - tendo como foco sua presença, supostamente transformadora na vida dos trabalhadores de Campo Limpo Paulista e cidades próximas - traz outro sentido às decisões de trabalhar nesta multinacional:

Situada na região de Campo Limpo Paulista, a ThyssenKrupp Metalúrgica Campo Limpo (CT-TKMCL) comemorou 50 anos de existência no Brasil em 17 de junho de 2011.

Sua chegada ao Brasil coincide com o início da indústria automobilística neste país.

Inicialmente planejada para a produção de locomotivas, a empresa teve seu foco rapidamente desviado para o setor automobilístico, o qual estava em rápida ascensão.

Naquela época, a empresa com uma área construída de $20.000 \mathrm{~m}^{2}$, a qual era um antigo armazém de café, tornou-se a esperança para a região. $\mathrm{E}$ atualmente há poucas famílias na região na qual não haja pelo menos um integrante trabalhando ou que já tenha trabalhado para nossa planta. ${ }^{4}$

Como prática recorrente em versões que enaltecem vantagens de seus empreendimentos, higienizadas de tensões e interesses de classe, o heroísmo burguês se formula nessa matéria indicando o "salvamento" promovido em benefício dos trabalhadores da empresa - no caso, os de Campo Limpo, Jundiaí e adjacências -, ao criar e disponibilizar vagas de trabalho. Propõe sintetizar um processo em que o sujeito coletivo - "a empresa" - se apresenta como protagonista de alterações significativas no processo produtivo e nas frentes de investimentos que procuravam nortear a expansão industrial brasileira de meados da década de 1950 e durante a década seguinte, voltada ao setor automobilístico.

Admitir que esta tenha respondido à "esperança para a região" é qualificar interesses empresariais como uma necessidade unívoca da "sociedade" por tal empreendimento, destituindo o inverso, que a Krupp se propunha internacionalizar sua produção durante a década de 1950 porque também necessitava baixar custos, ampliar mercados a partir de uma exploração sistemática e intensiva de trabalhadores. Tal propósito sugere uma rede de interesses envolvendo o Estado brasileiro e empresas como a Krupp.

\footnotetext{
${ }^{4}$ THYSSENKRUPP Metalúrgica Campo Limpo celebrando seus 50 anos. Notícias. Julho 2011. Disponível em: http://www.thyssenkrupp-forginggroup.com/language-pt/news/2011_july.htm Acesso em: ago. 2011.
} 
Ao indicar que "atualmente há poucas famílias na região na qual não haja pelo menos um integrante trabalhando ou que já tenha trabalhado para nossa planta", a relevância dada à atuação/lastro da Krupp ao longo desses anos busca legitimidade no reconhecimento dos trabalhadores que transitaram pela empresa. A formulação desta “notícia comemorativa" não se interessou em destacar o processo da "integração", por quanto tempo, a partir de que relações e conflitos, isto é, para que decisões essas relações de trabalho foram pauta em famílias de trabalhadores "na região".

Os empregados não se limitaram ao universo de uma prática metalúrgica. Informam uma variável de expectativas e atuações que ultrapassam os liames da fábrica e os vínculos a ela, dando pistas a respeito de sua movimentação social. O trabalhador Josué, ao narrar como chegou à Krupp, explicita elementos importantes dessa relação:

\section{Pesquisador: E a Giaccomi foi seu primeiro emprego?}

Josué: Bom, de metalúrgica sim. Só que antes, desde dez anos, antes não tinha trabalho escravo, dez anos eu já trabalhava em armazém é... Teve uma zorra de emprego só que não era registrado, que ganhava o dinheirinho e assim pra mãe, na mão. Hoje não é mais isso, quem ganha, ganha é pra ele, a família fica vendo, não é isso? Eu senti isso. Meus dois menino sempre trabalharam, nunca deram comida em casa, porque eu não quis pegá! "Guarde pra vocês", mas comigo não foi assim, era o dinheiro pra mãe.

\section{Pesquisador: $O$ senhor então da Chialvo foi pra KRUPP?}

Josué: Da Chialvo fui pra KRUPP.

Pesquisador: E porque o senhor optou por ir pra KRUPP?

Josué: Porque era uma firma maior, melhor, e certeza de trabalhar o mês inteiro e receber o pagamento, porque lá não era.

\section{Pesquisador: Na Chialvo?}

Josué: Três, quatro, cinco mês, atrasava demais o pagamento! Eu era solteiro, então me aguentava, né? [...]

Pesquisador: Então o senhor casou quando tava trabalhando na KRUPP? Josué: Em Dezembro, em 16 de dezembro do mesmo ano eu me casei. Daí passei a morar aqui. Antes eu morava lá perto do Morando, lá em Jundiainópolis. ${ }^{5}$

O ponto de partida da entrevista foi o momento em que o trabalhador começou como metalúrgico. O interesse era identificar quando e como ele havia chegado à Krupp. Entretanto, essa intenção reapareceu juntamente com outras memórias de Josué. Ao retomar sua infância, pontuou a passagem pela Krupp como parte de um universo de

\footnotetext{
${ }^{5}$ Josué (pseudônimo). Entrevista realizada por Rinaldo J. Varussa. Jundiaí, 15 de setembro de 2010.
} 
relações de trabalho marcada por sua condição de classe, destituindo o provável enquadramento de sua vida enquanto reflexo da expansão industrial.

$\mathrm{Na}$ realização da entrevista, já com seus 60 anos, aposentado e vivenciando os limites auditivos provocados pelo trabalho na Krupp, Josué tem questões conflituosas para compor o modo como analisa e interpreta a sua trajetória de trabalho, pontuando relações contraditórias, entremeadas de conquistas e frustrações.

Como destaca em sua formulação, se esse trabalho "que não era registrado, que ganhava dinheirinho", relações hoje entendidas como trabalho infantil, que é a prática de crianças contribuírem com o orçamento familiar, em finais da década de 1950 se legitimava pela condição de classe experimentada pelos trabalhadores e explorada por aqueles que se utilizavam de seu trabalho. Portanto, ao falar de suas relações de trabalho desde os dez anos de idade destaca a obrigação e o compromisso de auxiliar na renda necessária em casa, "pra mãe, na mão”.

Josué manifesta certo orgulho por esse ato e, em sua condição posterior, um olhar crítico sobre as necessidades familiares e seu significado, sem continuidade nos estudos e com responsabilidades domésticas. O "guarde pra vocês", que mais tarde diria aos seus filhos, traduz, sobremaneira, seu interesse em destacar como contribuiu para a transformação dessa relação familiar, procurando não se identificar, nem mesmo manter as necessidades que afetavam a casa de seus pais. Para tal, insinua o excesso de trabalho a que se havia dedicado em certos momentos como alternativa para que seus filhos vislumbrassem alguns horizontes de atuação para mudanças.

Sua postura indica o comprometimento em garantir que eles tivessem como planejar a vida melhor, enfrentando, quem sabe, menos pressões e necessidades, operando alterações mais significativas na condição de trabalhadores. Em meio à formulação de suas intenções, expõe que trabalhar no final da década de 1960 e início de 1970 significava enfrentar certas dificuldades, mesmo existindo "uma zorra de emprego" sem registro, pois isto representava falta de garantia em receber o pagamento combinado com o patrão e a manutenção desse trabalho, um desacerto que expressava uma relação desigual e constantemente pautada por desmandos patronais. 
Ficar cinco meses sem receber impunha a necessidade de procurar novo trabalho. Se ainda era solteiro e podia contar, mesmo que pontualmente, com a limitada colaboração de outros familiares, essa não era uma situação que se pudesse manter por muito tempo, principalmente frente às suas intenções de casamento. Uma expectativa construída em associação ao interesse pelo curso de Ajustagem Mecânica no Serviço Nacional de Aprendizagem Industrial - Senai ${ }^{6}$.

Para ele, a intensificação da jornada, com trabalho e estudo, caracterizava o esforço para alterar suas relações. Trabalhar na Krupp parecia potencializar determinada expectativa que dialogava com necessidades e ambições de mudança. Na formulação deste trabalhador, a Krupp "era uma firma maior, melhor, e certeza de trabalhar o mês inteiro e receber o pagamento". A referência internacional, o que se produzia e o como eram construídas as relações de trabalho traziam, para trabalhadores como Josué, certa noção de que essa era uma relação diferenciada e que poderia ser-lhes favorável, mesmo na exploração de sua força de trabalho.

Com um encaminhamento aproximado, para Fernando, um ex-ferramenteiro, a experiência pode ser entendida como um trabalho melhor dentro do leque de vagas disputadas pelos trabalhadores ${ }^{7}$. O provável estímulo ao trabalho na Krupp é destaque em sua fala na seguinte dinâmica: "Por causa de salário foi muita gente que deixou as indústria aqui em Jundiaí e foi embora pra Krupp trabalhar. Porque tinha toda benfeitoria. Eles tinha ônibus, que pegava o pessoal aqui e levava lá, e trazia de volta”8.

A narrativa de Fernando sugere que a concorrência com as indústrias e oficinas existentes em Jundiaí causou certo deslocamento de trabalhadores para a Krupp. Entretanto, a partir de sua própria trajetória, a permanência nessa indústria, mesmo com

${ }^{6}$ O Senai fez parte do programa de incentivo industrial estabelecido no governo Vargas a partir do decretolei 4.048, de 22 de janeiro de 1942, instituindo-o como órgão subordinado à Confederação Nacional das Indústrias, deixando clara a parceria e proposta de direção que se firmava a partir de então entre ações do Estado e o empresariado. Sobre as ações na sociedade brasileira que fomentaram a organização do Senai e da formação para o trabalho, ver interpretação apresentada em Müller (2010).

${ }^{7}$ Fernando (pseudônimo). Entrevista realizada por Rinaldo J. Varussa. Jundiaí, 16 de setembro de 2010.

${ }^{8}$ Muito deste percurso ainda se mantém entre as cidades limítrofes de Jundiaí. Ônibus intermunicipais e trens metropolitanos levam/trazem, diariamente, um número significativo de trabalhadores, ampliando assim o campo de trabalho para além dos locais em que muitos trabalhadores residem. Conferir esses apontamentos em Marques (2008). 
as "benfeitorias" tidas como novidades - salário, transporte, lanchonete à disposição, assistência médica - não garantiram sua presença por mais de um ano, tendo trabalhado apenas entre 1962 e 1963.

A rotatividade nos postos de trabalho é uma prática comum entre os trabalhadores. A tênue separação entre expectativa de estabilidade e mudança de trabalho se deve a um conjunto de avaliações e pressões, desde o que se firma nessas relações de trabalho até as alternativas vislumbradas e as prioridades eleitas como padrão de vida desses sujeitos.

Ao buscar elementos que inserem na visibilidade da Krupp um interesse e prestígio internacional, Fernando faz isso dialogando com os propósitos explícitos na produção da entrevista, afirmando que "na época, em 1962, era considerada o maior forjado da América do Sul, né? Naquele tempo não tinha aqui... Só tinha a Krupp mesmo aqui na América do Sul". O pesquisador, ao indicar os trabalhadores e o trabalho na Krupp como foco de análise, incita Fernando a atribuir certa relevância à própria condição da empresa, como também à sua presença nesse processo.

O breve ano em que Fernando permaneceu na Krupp é mencionado como um tempo difícil e limitado pela "arrogância" do encarregado, mas que lhe poderia ter rendido mais, haja vista a menção que faz à referência da Krupp na América do Sul. Ao recompor a sua trajetória, a formulação "eu rodei” expressa como avalia as conquistas que outros trabalhadores tiveram - seja ficando na empresa, seja saindo dela - em relação ao que construiu como perspectiva pessoal.

Neste sentido, ele ultrapassa a grandiosidade da empresa para pensar como sua experiência traduz insatisfações, e reconhece a limitação das aspirações de certos trabalhadores, o que explica grande parte de sua recusa inicial em fazer a entrevista e até sua reticência em rememorar a trajetória após a saída da Krupp:

Eu vim pará numa oficina que tinha aqui [...] pertinho de casa [...] acabei aposentando como mecânico de manutenção [...] Foi uma luta, certo? E aí, o que eu consegui na minha vida foi comprar essa casa aqui, financiada pelo BNH, né? [...] E criei os meus filhos [risos]. ${ }^{9}$

\footnotetext{
${ }^{9}$ Fernando (pseudônimo). Entrevista realizada por Rinaldo J. Varussa. Jundiaí, 16 de setembro de 2010.
} 
Fernando não apresenta esse percurso como algo a ser ovacionado, mas retoma a compra da casa e o criar os filhos como valores mantidos ao longo de sua vida, apesar de ter saído da Krupp. Acredito que parte da grandiosidade atribuída à empresa, lembrada como referência nessa conversa, se sustenta por seu afastamento desse trabalho, assim como pela dureza experimentada em relação a outras rotinas de trabalho, nas quais identifica dificuldades que, associadas à trajetória de outros trabalhadores com quem conviveu quando esteve na Krupp, talvez pudessem ter sido minimizadas.

As considerações oscilantes sobre a presença desses trabalhadores na Krupp emergem de imagens que permitem evidenciar o campo de trabalho metalúrgico como uma "novidade", na década de 1960, que arrefecia algumas pressões: "não tinha como nós recusar, porque era muita coisa prum lugar que ainda tava começando, né? Não tinha muita opção, né?". Mas, apesar desse horizonte de pressões, talvez Fernando também estivesse mencionando opções que não estava disposto a considerar, frente ao modo como desejava viver.

Para ele, como muitos que viviam em Jundiaí, podia ser difícil não reconhecer como relativamente proveitosa a condição da Krupp nas relações de trabalho, possíveis naquele momento, ou mesmo durante períodos de desemprego. $\mathrm{O}$ alto investimento na fixação do mercado automobilístico no Brasil, principalmente a partir da década de 1950, busca instigar o interesse por essa modalidade de trabalho, motivando a profissionalização industrial como alternativa para conquistar uma vida melhor.

Empresas como a Krupp adequaram seus interesses de produção no País e se inseriram no campo crescente de autopeças. O mercado de caminhões, que se apresentava como motivador do transporte interestadual de mercadorias, alinhavou, em grande medida, os novos empreendimentos da empresa no País, junto à expansão do mercado de automóveis.

As colocações de Negro (1997) - discutindo a implementação da indústria automobilística no ABC paulista, durante o governo Juscelino Kubitschek — inserem-se no debate sobre como se deram as alianças para a promoção desse setor industrial. A “operação mão-de-obra”, analisada pelo autor, é apresentada por ele como uma decisão 
estratégica de classe, inserindo-a entre os ganhos e benefícios plausíveis aos investimentos e "associação entre Estado, capital nacional e capital estrangeiro" para a instalação, por exemplo, de empresas do porte da Krupp para incorporar trabalhadores vindos da Região Nordeste.

Embora essa leitura estrutural indique um conjunto de trabalhadores sendo “conduzidos”, pela primeira vez, ou não, a essa relação de trabalho, é perceptível como esse processo não era tranquilo para o dirigismo proposto. O campo de promoção de cursos, dentro e fora das empresas, como também uma propaganda intensiva para promover essa prática profissional, e o deslocamento de trabalhadores para essas frentes de trabalho exigiram empenho e rearticulação de interesses para promover determinada expansão para suplantar outras frentes.

O princípio motor de tal empreitada significou, certamente, uma proposta de ação da expansão capitalista, talvez não tão homogeneamente arquitetada como chega a insinuar o autor. Entretanto, as relações narradas por trabalhadores que experimentaram esse processo recompõem uma trama de fluxo e refluxo de produção e fixação de trabalhadores bem mais intensa e contraditória, que ultrapassa a mera constituição de um mercado de mão-de-obra para atender à demanda.

Todo esse processo se dá, expressamente, porque trabalhar no ramo industrial é um dos campos de atuação a serem considerados e enfrentados pelos trabalhadores, apesar de as avaliações empreendidas por estes sujeitos não precisarem nem deverem ser entendidas como atos de autonomia e/ou consenso, uma vez que a realização desse projeto de exploração industrial não está imune a relações de tensão e confrontação de classe.

Ainda hoje, a significativa procura pelos cursos do Senai não determina, a priori, o percurso a seguir. Muitos trabalhadores se recusam a caricaturar uma "identidade metalúrgica”, ou “industrial”, sem avaliar o que ela poderá proporcionar frente a outras alternativas. Pode-se dizer que essa profissionalização, quando existiu, deixou entreaberta uma alternativa frente a pressões vividas pelos trabalhadores, mas não 
determinou o imobilismo diante do peso das relações de trabalho industrial na feitura de suas práticas.

Os trabalhadores continuam avaliando a projeção de carreiras e ritmos de trabalho, como também as alterações significativas que poderiam ser efetivadas na sua condição de classe. Portanto, as vinculações entre trabalho e profissionalização não são instantâneas; são avaliadas constantemente pelos trabalhadores à medida que são vividas ou percebidas como possibilidades a estabelecer socialmente.

As vagas industriais de torneiro mecânico, desenhista industrial, ferramenteiro, dentre outras, apareciam para muitas famílias de trabalhadores como a formação aspirada para garantia de trabalho de pais e filhos, que percebiam a expansão desse mercado com traços cada vez mais nítidos desde a década de 1950 e 1960 - seja frente à instalação da Krupp, seja pela presença de outras indústrias que buscavam se firmar em um mercado acirrado, em que empresas com atuação multinacional disputavam espaço.

Essa qualificação, com raras possibilidades de ser financiada, ocorria muitas vezes com o avançar da idade e no período noturno, sendo conjugada com a jornada diária de trabalho. Para um conjunto de trabalhadores que vinha crescentemente enfrentando as mudanças do trabalho no campo, ao mesmo tempo em que vinham percebendo a crescente emergência de postos de trabalho na cidade, as mudanças e tendências das relações de trabalho eram lidas a partir do interesse em visualizar onde e como conseguiriam viver, ou, mesmo, onde e como conseguiriam trabalho e viabilizar mudanças.

Esta me parece uma leitura possível sobre o que estava em questão para os trabalhadores ao lidarem com o conjunto das transformações que se faziam no processo de industrialização da sociedade capitalista brasileira em meados do século XX.

Se as prerrogativas anteriores podem suscitar ponderações positivas ou favoráveis em relação ao trabalho na Krupp, assim como a respeito de sua importância no mercado industrial, isto é possível porque se reconhecem a tensão e o conflito como marcas de um processo social instituído na desigualdade de condições e na diversidade de caminhos para certos trabalhadores. E, por esse suposto, emerge o desafio de perceber o que os 
trabalhadores qualificaram como melhor, como mais relevante e/ou necessário frente à historicidade das condições vivenciadas e as expectativas vislumbradas.

Cláudio, trabalhador mencionado no início deste texto, propõe elementos que intervêm na avaliação e sentidos atribuídos ao trabalho e à sua condição de trabalhador. Ele faz isso ao destacar o seu percurso até Jundiaí:

\section{Pesquisador: Onde o senhor nasceu?}

Cláudio: Eu nasci em Indaiatuba [...] De lá, meu pai foi andando pro...que era tempo de...era...vamos dizer assim, das fazendas, né? Daí fomo pra Itupeva, aí em Itupeva, meu pai... meu irmão teve olaria, né? Nós tinha...a olaria era...Meu irmão arrendava, né? Ai, meu irmão casou, ficou eu, meu pai e minha irmã e viemo pra cidade. [...] Pra Jundiaí. A gente morava na Vila Progresso. Moro até hoje lá, né? [...] estou lá há quase 56 anos, que eu estou lá. Jundiaí...

\section{Pesquisador: Mas na mesma casa?}

Cláudio: Não, não. Eu morei na [rua] Fernando Arens, daí quando eu... meu pai... Aquele tempo era aluguel, né? Aluguel... Daí fui pra rua República, da rua República, eu casei, [rua] Emile Pilon. Hoje, tô onde eu moro, na [rua] Américo Faria, 348. E eu tô lá até hoje. ${ }^{10}$

Se o "tempo das fazendas" representava andanças para sua família, sua narrativa permite dizer também que o trabalho no campo atendeu, por muito tempo, à manutenção de uma trajetória de trabalho, mesmo que na desigualdade desse processo — ter, de tempos em tempos, que percorrer novas fazendas. Junto a essa dinâmica, de expulsão e limite de trabalho no campo, o casamento do irmão também rearticulou as expectativas de trabalho da família, pelas quais o negócio comum - a olaria - não conseguiu, por muito tempo, garantir o sustento de tanta gente com uma produção familiar.

Em finais da década de 1950, Jundiaí, cidade vizinha de Itupeva, era reconhecida por eles pela maior possibilidade de postos de trabalho e de novas tentativas de prosseguir a vida. Este foi o caminho que seguiram, lidando com o "tempo do aluguel", que rege parte de suas andanças na cidade, como também os trabalhos inconstantes e de baixa remuneração.

Para certos trabalhadores, a entrevista sobre os tempos na Krupp sugeria lembrar das confrontações construídas enquanto repertório de vida e trabalho que ultrapassavam

\footnotetext{
${ }^{10}$ Cláudio (pseudônimo). Entrevista realizada por Rinaldo J. Varussa. Jundiaí, 27 de dezembro de 2008.
} 
o seu tempo na empresa. Sua experiência destaca um processo conflituoso e em construção, que perpassa suas trajetórias e valores e justifica visualizar a Krupp nos horizontes de suas possibilidades.

Marcos é alguém que potencializou esta interpretação. Ele foi admitido na Krupp no início da década de 1970; também não compartilhou, durante a entrevista, apenas o que vivenciou nos anos de trabalho nessa indústria, mas atribuiu sentidos a determinada experiência social de mudança e enfrentamento:

Marcos: Então eu vim de Marília, lá nós plantava arroz, plantava feijão, milho, algodão, café, que tinha nós coía... Mexia o café, então era isso que nós fazia lá [...] Se arregistrei em Marília, fiquei lá... eu vim pra cá com dezoito anos, dezoito anos se alistei e vim embora pra cá [...]

Pesquisador: E como o senhor entrou na KRUPP, como foi pra arrumar emprego lá?

Marcos: Olha quando entrei... quando eu fui lá na KRUPP [1972] foi assim, eu cheguei e fui lá... aí eu fiz uma ficha lá... [...] fez uma entrevista comigo, pra eu ia entrar lá na forjaria, aí ele falou comigo "óh eu não posso é...ajudar você, por você aqui dentro, porque você não tem, você não tem prática de nada! E você nunca trabalhou em firma como que eu vou por você aqui!? E eu tenho quinhentos..." [...] naquela época tinha cinco mil empregado! No total! [...] eu ainda falei pra ele assim "óh, se eu nunca trabalhei, por que nem todos os homens que o senhor pegou aí já...já vem trabalhando em firma, pra mim poder ter prática, pra mim ter prática eu tenho que trabalhar, o senhor tem que me colocar eu aqui dentro pra mim trabalhar, o dia que o senhor me mandar embora e eu for em outra firma aí...eu vou fazer uma entrevista com uma pessoa como estou fazendo aqui, daí falar o senhor tem prática porque o senhor trabalhou lá, agora se eu nunca trabalhei como é que eu vou... como é que eu... eu não tenho prática [...] Tudo eu falei pra ele "a tá bom" "mas não eu não posso" peguei e fui embora, aí eu fui, então eu comecei a trabalhar, [...] eu não podia ficar... porque eu tinha vindo lá de Marília e eu entrei num... num negócio de...fundi... igual você falou poço artesiano, aí comecei a trabalhar um cara queria registrar eu, eu falei "não, não, não vô registrar" aí comecei ajudar lá de ajudante, fazê uma coisa, fazê outra, de ajudante, [...] na outra semana, eu morava sozinho num...num cômodo lá no Vianello aí a perua tava bi...bi...bi...Eu tava fazendo o almoço aí a perua chegou [...] "a KRUPP mando você... que é pra você comparecer hoje lá com todos os documentos", aí eu peguei todos os documentos e falei assim ó "então espera eu" que eu não tinha nem dinheiro pra...pra pagá a passagem de ônibus sabe...? porque eu tinha vindo do interior, daí eu fui pro dona da casa lá... "me empresta um tanto pra mi...pra mim vortá de lá pra cá”, aí montei na perua e já fui, aí chegue 
lá... já fui fazer o teste... aí já...já mandando fazer exame médico e tudo, passei e já comecei a trabalhar, ali mesmo, e me aposentei lá!"

À medida que transforma em ação o interesse em enfrentar mudanças, tanto quanto buscá-las, permite inferir o quanto sua trajetória tem de identificações com caminhos de outros sujeitos que atuaram com igual tensão. Sair do "interior" e tentar de alguma forma produzir ações em outros lugares aparece como a principal motivação para sua empreitada. A tentativa de mudar o vivido ganha dimensão polêmica nas memórias de trabalhadores como Marcos.

Ainda que muitos trabalhadores encontrem como resposta a falta de capacitação/habilidade necessária para as vagas disponíveis, poucas vezes isso indica que não insistissem em produzir alternativas nesse processo desigual. As entrevistas de trabalho se faziam explicitando proposições de convencimento e conflitos, tanto na disputa pelo dirigismo da contratação, quanto na avaliação dos interesses da empresa e os que motivavam o trabalhador.

Historicamente, percebe-se no setor industrial de produção o interesse pela definição de um “perfil de trabalhador”, principalmente ao anunciar vagas e promover entrevistas para contratação. Mas alcançar esse modelo, em sua plenitude, parece continuar sendo a utopia burguesa. Não é preciso negar a dominação de classes, nem desconhecer a permanência de um processo de exploração de classes para perceber o rosário de interesses não satisfeitos de patrões, entre eles a dificuldade em encontrar trabalhadores "livremente capacitados", plenamente disponíveis e satisfeitos em ser explorados.

Nessa interface de interesses, entre patrões e trabalhadores, Marcos, ao retomar a disputa por aquela vaga em 1972, revela questões importantes sobre o enredo dessa relação. A Krupp não tinha à sua disposição um mercado exclusivo e homogêneo; havia um vaivém de trabalhadores, muitos advindos de firmas menores e oficinas, assim como aprendizes de cursos técnicos e ex-trabalhadores rurais como Marcos.

\footnotetext{
${ }^{11}$ Marcos (pseudônimo). Entrevista realizada por Rinaldo José Varussa. Jundiaí, 27 de dezembro de 2010.
} 
O ritmo da pressão para a produção de mais trabalho não agregou, tranquilamente, ao trabalhador interesse em se fixar nessa relação de produção como algo naturalmente melhor. Esta permanência tem sido construída, em grande parte, sobre outras bases.

A movimentação social dos trabalhadores não se limita às mudanças de postos de trabalho e deslocamento (de uma cidade a outra, ou mesmo do campo à cidade); promove substancialmente a proeminência de expectativas e práticas voltadas à alteração da realidade social em que se percebe inserido. Nessa dinâmica, colocam-se em jogo o tipo de patrão e os padrões de vida que os trabalhadores se dispunham a enfrentar, assim como as proposições e os entraves que permeavam suas atuações. Acredito que, o buscar alternativas, o chegar e o partir constituem, do mesmo modo que a produção de novos caminhos e possibilidades, agenda de intenções dos trabalhadores nas relações capitalistas contemporâneas.

Marcos, mesmo com a negativa inicial da entrevista na Krupp, continuou morando em um cômodo, aceitando o trabalho temporário na construção de poços artesianos em Jundiaí e passando a sanduíche de mortadela - uma alimentação incomum à sua dieta alimentar no "interior", mas necessária na cidade, frente às restrições orçamentárias que experimentava naquele momento.

Como destaca, chegou a Jundiaí e começou a trabalhar. Foi lidar com a urgência que a dinâmica da sobrevivência impingia. Era preciso conviver e remediar as pressões cotidianas enquanto as mudanças, consideradas de maior vulto, ainda ressoavam como aspirações.

O serviço pesado - tanto na abertura dos poços, quanto no trabalho posterior, alcançado na Krupp - indicava o reconhecimento do que se fazia continuum nas alternativas que lhe pareciam possíveis. Marcos não estranhava essa prática, ou mesmo a falta de dinheiro, também presente no trabalho no campo. Tinha sim interesse em transformar os resultados desse trabalho, ponderando que conflitos e projetos ele estaria disposto a enfrentar. 
Os indícios sobre essa experiência industrial, ao menos para os que durante as entrevistas foram motivados a interpretar suas intenções e razões por trabalhar na Krupp, levam a conjugar esse processo com o interstício de outras avaliações e decisões tomadas sobre a realidade social em que estavam inseridos.

Portanto, ao propor constituir evidências sobre o enredo que configura a Krupp nos caminhos de trabalhadores em meados do século $\mathrm{XX}$, a explicação fornecida pelo trabalhador Fernando sugere quais seriam as motivações para a expansão de indústrias multinacionais no Brasil e, ao mesmo tempo, como o envolvimento com essas empresas constituíam alternativas para trabalhadores como Cláudio, Josué e Marcos.

Fernando apresenta uma relação de mercado que explicita a natureza desigual das práticas de globalização perante as condições de trabalho na sociedade brasileira no início da década de 1960, avaliando suas alterações subsequentes e confirmações no tempo presente:

O Brasil cresceu muito nessa parte por causa do tamanho do país; e também por causa da procura, né? Certo? Porque os estrangeiro vieram muito pra cá. Sabe por quê? Mão de obra barata. Entendeu? Então foi ... Até hoje tem algumas firmas vindo pra cá por causa da mão de obra que é barata, certo? Você vai ver na Alemanha, o salário base lá é 24, não sei o quê... marco. O salário base. O nosso aqui, na época... Até pouco tempo era dois e pouco a hora trabalhada, né? Dois e uns quebrado. Então lá, na Alemanha, era muito, certo? Eles não têm como abaixar o salário, eles deixaram subir muito o salário lá, não tem como abaixar ${ }^{12}$.

Para ele, a busca por "mão de obra barata" e a expectativa de avançar na concorrência pelo controle do mercado fez a Krupp redimensionar sua produção e seus custos ao reconhecer o Brasil como compatível às suas intenções. Fernando destaca um entendimento que circulava entre os trabalhadores: aquela empresa se propunha implementar relações de trabalho distintas e mais desiguais do que as construídas historicamente na sua sede alemã.

Uma escolha de "investimento" que leva em conta os países que oferecem menor resistência burocrática e, à primeira vista, menores entraves trabalhistas, fator decisivo

\footnotetext{
${ }^{12}$ Fernando (pseudônimo). Entrevista realizada por Rinaldo José Varussa. Jundiaí, 16 de setembro de 2010.
} 
nessa aliança para determinar sua instalação e permanência. Em outras palavras, indica condicionar sua presença à manutenção de privilégios para sua atuação no País.

Este repertório de expansão capitalista evidencia como é proposto o processo de globalização, intensamente marcado pelo interesse em mais garantias de isenções fiscais, como também por um modo peculiar de lidar com a realidade social, em que as possibilidades de trabalho em empresas como a Krupp, mesmo entendidas no campo da exploração, diluem-se em índices significativos de aceitação frente às pressões da sobrevivência e da inserção em novos padrões de carreira, produção, salário e consumo.

Estas considerações indicam, e até deixam claro que, apesar de admitida a desigualdade presente na intenção de instalar a Krupp no Brasil, muitos desses trabalhadores ponderaram como esse trabalho poderia ser qualificado como melhor e, ao mesmo tempo, “duríssimo” nas relações entre empregador e empregado.

Fernando dá pistas sobre esse mecanismo de controle e acolhimento, indicando que "praticamente, se nós quisesse morar lá dentro da firma podia [...] Só vinha em casa pra dormir, né? Porque lá tinha tudo lá dentro, né?".

Essa proposta, formulada em uma interpretação que faz pensar na ausência desses benefícios em outras empresas, não corresponde plenamente ao "tudo" que certos trabalhadores qualificam como suas intenções ou planos. Para Josué, a ambição em desfrutar de tempo livre com os filhos, ir ao clube, jogar futebol e ir à praia era premente, mas conflitante com o interesse em dobrar turnos e aumentar a renda para esse lazer.

Esta exploração era contraditoriamente compartilhada por muitos outros trabalhadores, como Marcos, que foi trabalhar na carga e descarga de caminhões, no contra-turno do trabalho noturno na Krupp, procurando aumentar sua renda, com o que potencializava a noção de que não era absorvido pela empresa, mas estava voltado ao que esperava do lado de fora. Muitos outros destinos eram traçados fora da fábrica, apesar do cansaço e da insistência da Krupp em contratar menos e fazer horas extras a mais. 
Marcos, ao narrar sua posição de trabalhador na Krupp e mencionar o trabalho de transporte de mercadorias, explicita os julgamentos preexistentes sobre esse trabalho de “chapa” e, também, como e por que essas alternativas são valoradas de modo distinto entre os trabalhadores.

mas só que não era...de chapa, de chapa não era... vinha pra descarregar, vinha... eles pagavam um "x" lá pra nós descarregar... descarregar carreta ou então carregar vagão, então a gente saia lá e trabaiava até meio dia, uma hora, depois ia dormir, durmia e a noite ia trabaiá... e aí tinha muitos amigos meu...que falava assim "o negão, vamo sair da KRUPP porque... vamo sair da KRUPP e vamo trabaiá aqui, que aqui dá mais... dá mais dinheiro!" e dava mesmo! Eu ganhei... eu trabaiava ali uma semana, eu ganhava mais do que na KRUPP... porque lá era... uma pauleira danada, aí eu falei assim "ah, eu não vou sair da KRUPP não!” aí depois a turma "aahah...". Muitos pediam as contas pra trabaiá ali, só que daí, oia o que foi, foi acabando, foi baixando, foi baixando, não é registrado... o cara não tem.. custo nem nada ali, só recebia o dinheiro de você, trabaiava ali, no outro dia gastava tudo, aí eu falei "ah, não! Aqui dentro da KRUPP eu recebo meu salário por mês dá pra mim fazer alguma coisa", você entendeu? Eu recebo, pago isso, pago aquilo, posso comprar isso, e aqui não dá! Eu recebo esse dinheiro, todo dia eu vou gastar, e gasta mesmo! Você com dinheiro no bolso, você tem uma nota de cinquenta conto, você trocou, já era... então eu fiquei, aí... já... eu encontro muitos amigos meu, encontro muito amigo meu, uns vem aqui em casa, outros ficam oiando o carro na rua "Oooh, negão você num... se eu tivesse escutado o seu conseio, hoje eu tava que nem você, eu tava...", graças a Deus eu tô bem mesmo... eu tô com saúde... tenho alguma coisa, recebo meu salário de aposentadoria, tá bom demais né? [...] ixxi eu ganhei dinheiro, mas só que eu gastava né? Aquele dinheiro que eu... que eu ganhava ali, aquele eu (palmas) gastava tudo! Agora o dinheiro da KRUPP eu segurava um pouco, sempre fiz isso. ${ }^{13}$

Esta dinâmica de acúmulo de atividades sugere observar como os trabalhadores reconheciam que, mesmo trabalhando, seu salário não era suficiente para fazer frente às pressões que sofriam e às expectativas que formulavam. Daí considerarem, para aquele momento, as horas extras e outros trabalhos como conjugações possíveis. Marcos deixa claro como a avaliação do que é o "seu trabalho" não está dada.

A recorrência do entendimento de que o trabalho na Krupp mantinha bons salários entra em dissonância com a narrativa de Marcos quando apresenta o trabalho de chapa como mais rentável (“uma pauleira danada”, mas “dá mais dinheiro”).

\footnotetext{
${ }^{13}$ Marcos (pseudônimo). Entrevista realizada por Rinaldo José Varussa. Jundiaí, 27 de dezembro de 2010.
} 
Mesmo que enfatize os limites desse ganho - ser diarista, sem vínculo empregatício, dependente da demanda de carga e descarga -, a decisão de turmas de metalúrgicos em se dedicar a outras frentes de trabalho quando estavam em alta permitia valorar a permanência (ou não) na Krupp. Também permitia perceber mais do que identificações com a categoria. Há evidências de outros interesses que na década de 1970 balizavam o "ser metalúrgico".

No momento da entrevista, Marcos valoriza sua decisão em permanecer na Krupp e indica que sua opção foi a mais conveniente, a longo prazo, principalmente pela manutenção do trabalho até se aposentar, por elementos positivos como a garantia de determinada renda todo mês. Declarar ter sido metalúrgico lhe dá notoriedade na relação com o pesquisador, principalmente ao indicar a condição de trabalhador chapa como um trabalho desqualificado frente ao exercido na Krupp, mesmo ganhando mais.

Marcos oferece uma interpretação contraditória com as possíveis categorizações. Ao rememorar sua trajetória de trabalho, procura indicar a predominância da atividade metalúrgica, enfatizando que, quando ponderou necessário, ainda que por um tempo determinado, se prestou à atividade de descarregar carreta e vagão, afirmando, no entanto, que isso não implicava ser chapa.

O entrevistado justifica essa compreensão ao confrontar suas condições atuais em relação aos casos em que a escolha de outras relações de trabalho por vezes eram mais valorizadas por serem mais apropriadas às necessidades de certos trabalhadores, tendo em vista, entre outros possíveis aspectos, a rentabilidade que proporcionavam na década de 1970 (sofreram mudanças expressivas nos períodos subsequentes, como foi o caso do trabalho de carga e descarga de mercadorias).

No interior da fábrica, a divisão entre os trabalhadores mostrava uma tênue e conflituosa distinção, seja legitimando ações, seja polemizando a dinâmica de produção. Marcos afirma que as pressões do trabalho não eram vividas por todos da mesma forma, nem com o mesmo peso. Uma ida ao banheiro mais demorada, ou uma passada mais prolongada no bar (lanchonete da Krupp), já indicava traços particulares nos sentidos atribuídos ao trabalho e à experiência construída: 
vez que...que eu ia no banheiro é... fazia um... fazia necessidade lá e...já vortava correndo, tinha "nego" que chegava no banheiro e ficava batendo papo, e... eu, como eu vim da roça... e pra mim... eu nunca vi dinheiro na roça... porque lá tinha o cabeça, que era meu pai, então a gente trabalhava... é...o ano inteirinho, chegava na... na coieita...coía arroz, coía feijão, ponhava no caminhão... vendia... e nós não via dinheiro, você entendeu? Lá na roça era.. .ele que era o cabeça... [...] meu pai ganhou tanto dinheiro lá que...que morreu e não deixou nada pra nós... gastou tudo! Não sei o que ele fez, nós trabalhamos a vida inteira inclusive, os irmão tudo... e ele nunca deixou nada pra nós! Morrendo... eu não posso recramar, né?... porque... eu graças a Deus se eu morrer amanhã, eu tenho três filhas, alguma coisa eu vou deixar pra elas... eu tenho essa casa aqui... tenho um terreno lá no Jacaré... mil metro, tenho uma casa na Vila Comercial, comprei essa outra casa aqui, eu tenho esse fusquinha véio, tenho outro carro novo que eu comprei agora tá com dois mês! Agora interou dez mil quilômetro tá lá fazendo...fazendo a primeira... a primeira revisão, comprei um Crossfox, paguei cinquenta e quatro pau! Tá lá... e eu nem quero trazê muito nessa... nessa estrada, porque senão... eu acabo com ele! mandei dá uma limpada nele lá e... deixar ele na casinha lá...lá tem um asfalto tem tudo. ${ }^{14}$

O caminho para narrar o ritmo da fábrica se entrelaça ao ritmo da vida. Marcos se refere a pressões e mágoas como marcas de trabalho intenso no campo e na cidade. Ele avalia sua falta de costume com dinheiro e sua necessidade em ganhá-lo, assim como fala das motivações de sua conduta; afinal, valoriza o fato de ter três filhas para criar.

Ao fazer isso, não é só o distanciamento de alguns companheiros de trabalho que apresenta, mas também sua tarefa de não repetir o que o pai lhe fez. Essa relação expõe sua noção de exploração. A vivência familiar que propõe na condição de pai sugere que suas três filhas terão os créditos do que conseguiu pelos 26 anos de trabalho, mas, principalmente, os bens advindos nas últimas aquisições com o término do processo contra a empresa, em razão dos danos auditivos sofridos. O que teria outra dimensão caso fosse contabilizar apenas o ganho salarial do seu trabalho.

Contudo, a quebra desse acerto de contas familiar e de exploração do seu trabalho acontece quando a vida é percebida de um modo menos linear, contrariando determinadas pretensões analíticas. Quando Marcos fala sobre a sua condição, ora casado, ora solteiro, a relação com as filhas aparece em uma dimensão mais densa:

\footnotetext{
${ }^{14}$ Marcos (pseudônimo). Entrevista realizada por Rinaldo José Varussa. Jundiaí, 27 de dezembro de 2010.
} 
Eu nunca casei, eu tenho três filhas, porque na época quando eu cheguei aqui eu conheci uma... uma mulher, uma mulher, então... ela já tinha dois filhos... aí ela... eu tive uma filha com ela, depois nós não demo certo...só que eu nunca morei com ela... aí ela pegou não quis tratar da menina... eu catei a menina e dei pra minha mãe... tratar, e ela continuou com a vida dela lá... aí nesse meio tempo eu arrumei outra... aí tive outra filha! Tive uma filha... mas só que com essa aí eu morei! Vinte anos... com essa mulher aí, com essa segunda, só que aí...aí...depois morando com ela vortei com a outra, [...] daí ficava com as duas...com as duas... ela me deu outra filha e por isso que eu tenho três filhas, aí depois [...] morreu uma, aí eu peguei arrumei uma lá de...de Bauru, aí eu... vivi...vivi com essa outra de Bauru, doze...quase dez anos! Aí eu morava, aqui com ela! [...] aí a mulher faleceu, faleceu tá com dois anos que ela faleceu! Agora eu continuo sozinho. ${ }^{15}$

O mudar a vida também se faz construindo amores e filhos para cuidar. Nesse sentido, Marcos, entre idas e voltas, aumentou os seus gastos com as parceiras, como também aumentou o número de filhas. Grande parte do que disse na entrevista envolvendo o "gastei demais" e "trabalhei muito" perpassa suas diversões e compromissos familiares, ajuda nos gastos de sua mãe nos cuidados com uma de suas filhas, bem como o sustento das outras duas e a expectativa de uma casa nova e carro novo na garagem.

Colocações como as anteriores enfatizam o modo como essa proposta de expansão industrial trata não só de mudanças na produção e no onde produzir, mas altera as relações e o direcionamento da ocupação dos trabalhadores, ou melhor, nelas intervém mais profundamente. A própria condição desse trabalhador em lidar com o tempo, com certas noções de trabalho e a dinâmica de sua vida está no foco da disputa da empresa por sua "dedicação e compromisso com o trabalho".

Evidentemente, para a promoção desse projeto é preciso, mesmo em tensão, potencializá-lo na proporção das expectativas de grande parte dos trabalhadores. Entretanto, é preciso avaliar como eles veem e constroem essa relação e com que frequência, pois, numa relação de eventuais sucessos da empresa que lhes garantiria e permitiria um projeto que poderiam valorizar como "seu" - aumento salarial, ascensão na carreira, etc. —, também têm consciência da desigualdade nessa "parceria".

\footnotetext{
${ }^{15}$ Marcos (pseudônimo). Entrevista realizada por Rinaldo José Varussa. Jundiaí, 27 de dezembro de 2010.
} 
A cadeia hierárquica que compõe o mando do chão da fábrica carrega contradições em relação às identificações e dissidências entre esses diferentes e desiguais trabalhadores, pois, se um dia já se viram na mesma linha de produção, em determinados momentos explicitam diferenças que geram confronto de interesses classistas, principalmente quando assumem lugares distintos na relação de trabalho.

Marcos destaca o momento de sua ascensão na carreira como o período em que vivenciou maior pressão ao lidar com os dois lados da moeda, mesmo que essa condição fosse almejada e lhe garantisse a valorização do seu percurso profissional:

porque você sabe se... se chegar numa firma aí... se você for um chefe, um gerente, se tiver cem.. cem...pessoas e você sozinho com aquelas cem pessoas... se eles quiserem tirar você da firma eles tiram, sabe disso né? A firma... o cara fala... "aquele cara... vamo queimar ele?" "vamo!" "Vamo fazer isso?" “vamo!", aque... aqueles cem caras para a máquina e fala "ó, tira esse homem daí, senão, nós não vai trabaiá!". A firma não vai mandar cem e deixar você, ele tira você e deixa cem ali, não é assim que a firma faz? ${ }^{16}$

Ao exigir alguma posição dos trabalhadores - em questões de horários e produção -, sabia que era necessário associar sua condição de trabalhador para poder ter algum êxito. Tudo isso, por entender que numericamente faziam a diferença e, mais que isso, por reconhecer o lugar que ocupavam na relação de produção. Afinal, se não produzissem, ele também seria culpado.

$\mathrm{Na}$ tradução de tempos sem datas, mas que foram marcos desse trabalho na Krupp, nosso entrevistado destaca que as pressões não estavam apenas nesse dia a dia de produção, pois a possibilidade da demissão acompanha a prática do trabalhador, exigindo uma leitura da dinâmica da fábrica que permita aos trabalhadores caminhos alternativos em períodos críticos e de possível conflito pela disputa por vagas.

Em alguns momentos, à medida que o trabalhador acredita que a surpresa da demissão é o pior que poderia lhe acontecer, é preciso antever esse enfrentamento:

teve uma vez que [...]. a turma tava saindo de férias... tava fraco lá... a turma tava saindo de férias, e quando voltava mandava o cara embora! $\mathrm{E}$, eu tô... tava pensando, "caramba, tão mandando todo mundo embora, turma sai de férias manda embora...volta manda embora". Porque tava

\footnotetext{
${ }^{16}$ Marcos (pseudônimo). Entrevista realizada por Rinaldo José Varussa. Jundiaí, 27 de dezembro de 2010.
} 
fraco sabe? Aí quando chegou minha vez... me chamou eu lá... "ó, você vai sair de férias... tal, tal", eu falei... caramba vou sair de férias, quando eu voltar eu vou pra rua! Aí eu cheguei e falei pro chefe, falei "ó, é o seguinte, eu vou sair de férias!?", "vô", falei "então é o seguinte, eu tô vendo que todo mundo tá saindo de férias que quando tá vortando, vocês mandam embora, então eu quero sabe... se for pra vocês me mandar embora... eu vortá e manda eu embora, então você me mandam eu agora, com a féria... já pego dinheiro da férias e tudo e saio" "hã...não... porque talvez...a firma tá fraca... mas não vamo manda você embora... se melhorar você continua, se não melhorar nós tem que fazer alguma coisa!" eu falei "não, não! Ou melhora, ou não melhora... eu não vou aceitar isso... eu vou assinar férias... se vocês dá... a decisão aqui agora pra mim, se for pra a hora que voltar... e você me mandar embora, pode me mandar embora agora!" Né não!? Não é assim que você tem que fazer!? Porque se você... dá féria você gasta o dinheiro...tira metade do décimo terceiro e gasta o dinheiro... e depois...eles chegam e te mandam sem dinheiro embora! Então não adianta. ${ }^{17}$

Marcos recoloca sua decisão sobre as férias ao perceber que as demissões que estavam acontecendo não eram ações individualizadas, mas uma recorrência que colocava os trabalhadores numa condição comum de classe: a da possibilidade e experiência do desemprego. A dinâmica capitalista não mudou nesse aspecto. A demissão ainda funciona como restrição de custos para garantia do capital, assim como estimula a intensificação da exploração dos que permanecem.

A ênfase de Marcos em saber o que irá lhe acontecer para determinar o destino do dinheiro das férias sugere pensar sobre o modo como os trabalhadores decidem e priorizam gastos. Neste caso, Marcos abriria mão de gastar com as férias para lidar com o período de desemprego, não estando disposto a piorar ainda mais sua situação, isto é, ficar sem trabalho e sem dinheiro. Estes são alguns dos limites que definem o orçamento, o onde e como trabalhar e viver.

Acredito que compreender o processo no qual o empregado está inserido faça parte da construção de atuações visíveis, tanto em períodos de insegurança no trabalho, como também em seu extremo, o de plena produção, garantindo enfrentamentos de maior afinco pelo excesso de trabalho e metas de produção. Influir no encaminhamento de decisões referentes às relações de trabalho é uma prática dos trabalhadores,

\footnotetext{
${ }^{17}$ Idem.
} 
construída historicamente em uma identificação de lutas e desigualdades comuns diante das exigências históricas de confrontação.

A prática de guardar dinheiro, precavendo-se de necessidades, ou de promover um ganho que permita acumular rendimentos para fomentar escolhas em campos de pressão permite dialogar, nessa dinâmica de transformação, com diferentes necessidades, valores e objeções. Esta visão pode traduzir-se também no interesse em amortizar as desigualdades experimentadas socialmente, revestindo a perspectiva de relativa segurança, estabilidade e mudança na eventualidade de sua força motriz passar pela necessidade de sobrevivência.

Para Josué, foi assim que a adesão às horas extras, em alguns momentos, se reverteu a seu favor:

Bom, no começo... no começo... é... eu trabalhava quinze horas, entrava uma e meia em serviço e saia cinco da manhã, ia pra casa dormia um pouco, voltava, entrava uma e meia e saia cinco da manhã, então foi muito, muita hora, as vezes tinha mês que fazia mais hora extra do que normal. Então, quer dizer, isso aí era um ganho muito grande, e aonde a gente foi conquistando e guardando e chegamo a hoje né? Mas, assim, sempre como operador de máquina! ${ }^{18}$

As horas extras apareciam como uma ampliação das possibilidades, não necessariamente acompanhadas de promoção de cargo ou de um serviço mais leve. Para o trabalhador, o acúmulo de horas pôde, muitas vezes, materializar-se na compra da casa, do carro ou em viagens. Por outro lado, não garantia o tempo almejado para usufruir dessas aquisições, ou mesmo partilhar regularmente de espaços de sociabilidade. Josué, contraditório, mas lúcido a respeito de sua condição, constrói, durante a entrevista, sua narrativa destacando a natureza de suas relações de trabalho e como avaliou que não vivenciou mera exploração, pois valorizava sua atuação nesse processo.

Em sua fala, não destaca traços de benevolência empresarial na Krupp, mas a insistência em assinalar que o que conseguia era resultado de sua intervenção naquela relação, que ele valorava como conquista: “arrumei minha vida, isso é importante, né?”

\footnotetext{
18 Josué (pseudônimo). Entrevista realizada por Rinaldo José Varussa. Jundiaí, 15 de setembro de 2010.
} 
Ao falar disso, ressalta sua ação indicando que tinha projetos e clareza sobre o que pretendia alcançar, mesmo no campo de forças desiguais nas relações de trabalho. 0 "conquistando e guardando e chegamo a hoje" revela uma maneira de dimensionar perdas e limites dessa conquista - sem ascensão na carreira e problema auditivo - e que o ter sabido lidar com isso não o impediu de interferir nos ditames de horários, turnos e, ao mesmo tempo, comprometer-se com a produção, garantindo, na ambiguidade, sua confrontação e prestígio como trabalhador eficiente.

Josué fez questão de ressaltar que o excesso de trabalho era uma relação temporária, comum, porém, em diferentes momentos, necessária aos trabalhadores e à empresa. Para ele, sua necessidade se situou nos primeiros anos de contratação. A narrativa do entrevistado evidencia como certos trabalhadores dialogam historicamente com a exploração do trabalho. Josué enfatiza que "no começo" era preciso garantir o trabalho, mostrar serviço, e isso justificava trabalhar mais. O que não impediu que situações semelhantes se repetissem ao longo de sua trajetória na empresa, em que se sentia extremamente marcado pela pressão para garantir o trabalho, os espaços e as condições conquistados na firma. Um limite de decisão constantemente utilizado nas relações de trabalho.

As práticas do chão da fábrica impõem um ritmo extenuante de produção e entrega de mercadorias, o que impõe limites às escolhas e mudanças dos trabalhadores em caso de recusa de horas extras, de mudanças de férias, etc. Mas essa decisão é construída nesse convívio, muitas vezes delimitada pela proximidade, ou dissidência, com certas chefias, na visibilidade da valorização de seu trabalho e nas reticências do mandonismo.

De outro modo, se a chegada dos filhos pressiona o orçamento familiar, e isto leva, por sua vez, a se assujeitar a horas extras, este também é um momento em que se fragiliza o tempo para a empresa, senão pela alteração deste padrão, ao menos pelo desconforto de ficar ausente de casa. Josué argumenta que exceder o turno, a não ser em momentos de grande pressão - sua ou da empresa -, não era de seu interesse. A quebra da possível lógica de dominação estrutural, ou de apologia ao trabalho, só é 
alienado das questões que determinados trabalhadores se colocam na constituição de sua experiência social. Ele reconhece em que lugar desse campo de forças ele se encontra quando menciona que "isso aqui não é eterno pra mim". O entrevistado reconhece como funciona essa dinâmica de exploração do trabalho e onde esteve todo o tempo: "sempre como operador de máquina”.

Atualmente, as avaliações produzidas pela empresa sobre a implantação do "trabalho padronizado" indicam o maior aproveitamento desse trabalhador sem gerar horas extras, como um resultado não só satisfatório, mas de eficiência produtiva, recuperando o equivalente a duas horas a mais de produção (KISHIDA; SILVA; GUERRA, 2006). Um encaminhamento no qual o trabalhador tem sua condição depreciada e a maisvalia se sobrepõe à sua posição de sujeito nessa relação de trabalho. A máquina apresenta-se como interface decisiva desse processo (MARX, 1983).

Telles, em pesquisas recentes, apresenta-se incomodada com as relações de trabalho e o modo como os trabalhadores se posicionam nestes enfrentamentos. Sua intenção passa por apresentar as etapas constituintes do que denominou "mutações do trabalho", procurando discutir certas alterações nas relações e práticas dos trabalhadores, consideradas explicativas do processo atual a partir de distintas gerações.

A autora observa as mudanças nas contratações e relações de trabalho na sociedade brasileira contemporânea, tentando dar conta de sua historicidade a partir do que evidencia no tempo presente como “desagregações do mundo fordista”. Em sua perspectiva, isto poderia significar uma tendência do encaminhamento das relações de trabalho firmadas até o momento.

Sua percepção tem como pressuposto um enfrentamento teórico, que continua mantendo o modelo fordista como parâmetro, propondo "ressituar o trabalho no mundo social” em um novo paradigma (TELLES, 2006). Suas ponderações supõem aceitar 

apresentar cenários de relações de trabalho em que a análise geracional comparada lhe permite avaliar mutações e experiências, no que ela chama de "mundo social redefinido". Deste modo, não enfrenta fissuras ou mesmo contradições no modo de constituir tais experiências.

Sua interpretação tipológica e de proposição homogeneizante tem como suposto um momento ideal em que o "mundo fordista" determinou totalmente as relações de trabalho. Uma proposição sobre a qual faço minhas ressalvas, pois perde, em grande medida, a dinâmica de mudanças e permanências na vida desses trabalhadores, pois não leva em consideração transformações e confluências de costumes que informam o modo e as condições desse trabalhar para além de "encantamentos faiscantes" recentes, sugeridos em sua formulação. Haja vista que as experiências, constitutivas das trajetórias desses trabalhadores, não são enunciadas em épocas homogêneas, ou em modelos funcionalistas herméticos.

Para essa sociologia, a afirmação da noção de que "o trabalho não deixa de ser uma dimensão estruturante da vida social" parece exigir que se tomem os trabalhadores como mero material humano do processo de produção capitalista. Mesmo para autores que, como ela, se dispõem a problematizar explicações economicistas e estruturalistas, evidenciando a obviedade da existência de trabalhadores que participam nos modos de produção social, o material humano, neste caso, ainda não deixou de ser visto como fator de produção.

Ao ver os trabalhadores como personagens ilustrativos desse mundo social, centrados no trabalho como estruturante das relações, a autora reduz seu protagonismo, colocando-os na dinâmica de uma engrenagem do "mundo do trabalho", condição preexistente às relações desses sujeitos.

Acredito que as divergências relativamente a esta percepção podem ser situadas na postura firmada no presente texto, em que os trabalhadores mostraram ser capazes 
de perceber e recompor suas práticas no campo de forças sociais em que formulam suas relações, não se restringindo a atuar em um quadro delimitado pelas etapas de desenvolvimento industrial - antes ou depois do modelo fordista, ou até mesmo durante.

Na contramão da constituição de cenários de trabalho e de vida, explicitar a materialidade desses enfrentamentos é reconhecer um enredo de conflitos e projetos desiguais para tal sociedade. É reconhecer que pressionam por novas estratégias capitalistas de controle e organização social, da mesma forma que nos impelem a propor interpretações mais plausíveis, não do mundo do trabalho, mas do que entretece práticas e percepções de trabalhadores.

A noção de "mutações do trabalho" enquanto possibilidade interpretativa não explicita as transformações experimentadas pelos trabalhadores, mas as expõem como dados descritivos de uma realidade, fazendo desse caminho investigativo um teorema que antecede a prática dos sujeitos sociais. A centralidade do trabalho, entendida como chave de acesso à dinâmica social não permite, muitas vezes, evidenciar a relevância dos trabalhadores na proposição de tensões e alterações significativas nas relações de trabalho; talvez tenhamos de repensar a centralidade deles nesse processo.

Neste sentido, as doenças que os trabalhadores vivenciam por excesso de trabalho - má postura, acúmulo de atividades, dentre outras limitações de suas condições - são elementos que interferiram também nas alterações de sua rotina de trabalho e de produção. Eles informam que as razões pelas quais continuam a ser recorrentes, em suas diferentes formulações, quase sempre convergem para a compreensão de relações historicamente marcadas pela exploração do trabalho, o que explica doenças, acidentes e restrições de horários e pagamentos, além da continuidade dos confrontos nas relações de trabalho.

Lúcio, ex-trabalhador da Krupp, destaca, em sua fala, as dores no ombro e braço que sentia em 2009, últimos tempos em que trabalhou na empresa. Repetir atividades e manusear a talha durante o turno inteiro - instrumento que fazia o transporte da peça provocou-lhe dores durante noites, obrigando-o a um uso intensivo de medicamentos. ${ }^{19}$

\footnotetext{
${ }^{19}$ Lúcio (pseudônimo). Entrevista realizada por Rinaldo José Varussa e Vagner José Moreira. Várzea Paulista,
} 
Se a saída da Krupp ainda é avaliada por contratempos e gastos — por perder os "benefícios" que acompanham o salário -, as dores constantes, o cansaço e o nervosismo ainda são, pelo menos por enquanto, amenizados.

Se essa realidade faz parte da pauta recente de problemas vinculados à produção, os trabalhadores que estavam nas primeiras décadas de funcionamento da Krupp tiveram problemas de coluna e, expressivamente, de perda auditiva, causas comuns de demissão, processo de indenização ou de aposentadoria.

O excesso de trabalho em ambiente de muito ruído - o que permanece no tempo presente, mesmo com o uso dos equipamentos de segurança - não permitiu a muitos trabalhadores que estiveram na Krupp, entre as décadas de 1960 e 1970, saírem ilesos das marcas desse processo e das condições de trabalho impingidas à sociedade contemporânea. Josué destaca que seu caso não foi exceção:

Pesquisador: Como você adquiriu esse problema no ouvido seu Josué? Josué: Quando eu entrei em 72 a firma não tinha protetor de ouvido e... a sessão era fechada, então a minha máquina não fazia barulho, mas a máquina do meu vizinho ali fazia barulho. [...] Então onde se trabalha oito horas, oito horas aquele negócio na sua cabeça, precisa ficar até mais tarde, já não vai mais ser oito hora, vai ser mais! Vai ser doze, as vezes quinze! [...] Antes era 48 horas por semana, era seis dias de oito horas, então o sábado que agente entrava da uma e meia as dez, a semana inteira né?[...] Aquilo foi apertando né? Subia, subia, ar comprimido né que os cara usavam pra limpar a peça, foi complicando, complicando e em 78 eles introduziram os IPI era os aparelhos né... pra evitar! Mas eram coisas muito ruim, se colocava um abafador, tive por cima assim! Igual o negócio do som aí... Dava um esquentamento no ouvido que você não conseguia usar, aí tinha umas esponjinha também...colocava dentro do ouvido, aquilo dava uma coceira, mas só que daí é o seguinte já rodou seis sete ano né? Inclusive as pessoas que trabalhavam antes de mim, ou na época que eu entrei até um pouquinho mais até quando introduziram isso aí é tempo demais... [...] Que nem domingo agora teve churrasco lá no sindicato [...] o pessoal que entrou antes de mim tava tudo lá! Aí todo ano a gente faz encontro então é uma beleza pra rever os amigos né!? Alguns você quer ver, alguns você não quer ver, tem de tudo... Então quando você vai conversar com o cara... Tudo assim... Tudo assim! O prejuízo ficou, o dinheiro ajuda? Porque é uma incógnita, porque era bem melhor tá bom do ouvido! Dinheiro é um complemento pelo acidente que você teve, mas que não te ajuda, não te ajuda! Porque era melhor... Eu tô aqui sentado lendo o jornal, tá a minha

14 de março de 2011. 
mulher lavando louça... o telefone toca lá na sala, ela fala assim: "o telefone tá tocando!” e eu continuo lendo o jornal! Então ela vira pra mim: "Telefoooooooooone!" aí se eu tô com aparelho eu vou lá atendo "alô..." mas se eu não tiver prestando atenção eu não escuto. [...] Da minha época acho que $80 \%$ teve esse problema. ${ }^{20}$

A indicação dos resultados dessa relação de trabalho por Josué é traduzida como uma "incógnita", que prefiro situar como contradição, tanto pelo seu fazer, como pela forma de encaminhar soluções referentes à exploração do trabalhador. Haja vista que a indenização e a vivência do problema auditivo não se equivalem e raramente são reconhecidos pelas empresas sem a intervenção judicial do trabalhador, o que nem todos experimentaram como conquista privada de intimidações e conflitos.

O custo avaliado de sua saúde - destacando apenas o desgaste auditivo - pode possibilitar ganhos que reponham sua inserção social e suas condições de vida - casa, carro, pagamento de contas, mas não apaga o quanto essa prática de trabalho foi intensa e ignorada nas décadas iniciais de sua implementação, o que se expressa no número significativo de trabalhadores que enfrentam tais problemas no presente, no lazer com amigos, na rotina familiar, ou mesmo numa entrevista como esta.

O melhorar a vida, justificado por muitos trabalhadores para suportar essa rotina de trabalho, é uma avaliação que também tem seus reveses. A pressão exercida por um trabalho pesado é redimensionada na crueza do fazer dessas relações de produção, principalmente ao lidar com desgaste laboral provocado, a médio e a longo prazo, na saúde desses trabalhadores - exigência de força física, rendimento em longas jornadas e, posteriormente, a preponderância da "eficiência" no uso do maquinário, indicando agilidade na produção e comprometimento com os resultados da empresa.

Marcos exalta sua resistência física e o modo como a construiu em sua trajetória de trabalho. Sua formulação admite uma continuidade de desgaste e esforço e, nesse mesmo percurso, indica em que bases a Krupp tinha trabalho "pesado" e uma dinâmica austera nas décadas de 1970 e 1980:

na época que eu trabalhava lá, quando eu entrei, nêgo ... quantas e quantas vezes nêgo desmaiava assim, você passava por cima do cara...

\footnotetext{
${ }^{20}$ Josué (pseudônimo). Entrevista realizada por Rinaldo José Varussa. Jundiaí, 15 de setembro de 2010.
} 
porque não podia jogar a peça no chão. O cara caído, você passava por cima e ponhava a peça lá, [...] porque os coitado não aguentava, não aguentava,[...] da vez os cara não...não... sei lá, aí cai... caia a turma pegava saia correndo com o cara, levava tomar soros, era assim! É, foi cruel quando entrou, hoje não! Hoje tá tudo fácil lá pra trabaiá, hoje quarquer pessoa que chega lá, pega e faz o serviço, você entendeu? Mas, antigamente era difícil, antigamente era pesado, ixxii nossa senhora... eu lembro muito bem que...quando eu entrei lá dentro vixxii, eu fiquei lá dentro.. porque... eu lá na roça era acostumado a trabaiá, trabalhava é... batendo amendoim, cortando arroz, quebrando milho, carpindo, então fazia de tudo lá na roça é... quando dava dia de chuva, nós pegava de... eu não guento dois saco de... ninguém guenta dois saco de arroz... cheio, e lá quando dava chuva, que a água vinha assim ó... enchia o vajão, então nós pegava dois saco de arroz assim ó... e ia dentro d'água puxando até sair lá fora que era pra água não levar embora... era um sofrimento rapais... um sofrimento na roça! Depois que eu entrei aqui pra mim éé...era (palmas) café pequeno! ${ }^{21}$

O narrar de Marcos desafia a reconstruir esse universo de pesquisa acadêmica sobre a condição de classe dos trabalhadores. Os olhos inicialmente voltados para o trabalho industrial permitiram reconstituir a maneira como se engendra o que Marcos sugeriu como "costume por trabalhar". A ampliação desse foco foi dimensionada com verbos que colocaram em movimento sua experiência: batendo, cortando, quebrando, carpindo, puxando.

Acreditou valer a pena recompor, nas suas memórias, um costume que mudou, o que avalia como uma alteração qualitativamente melhor, dizendo: "[era] um sofrimento na roça". Por isso, aguentar o que se passava na Krupp, com desmaios, desistência de colegas, com trabalhos extras ao sair do turno é indicar o quanto já se havia alterado sua condição de trabalhador. No entanto, deixa claro que ainda persiste o que avaliou como uma relação "cruel”.

Os custos da melhoria vislumbrada no trabalho na Krupp vêm à tona desconstruindo certa identificação estática que, à primeira vista, se possa enunciar. Haja vista que esse lugar de estabilidade profissional, quando se fez, foi, em grande medida, balizado em horas extras, doenças, ritmo de trabalho excessivo e em uma progressiva rearticulação da condição salarial e de expectativas na carreira.

\footnotetext{
${ }^{21}$ Marcos (pseudônimo). Entrevista realizada por Rinaldo José Varussa. Jundiaí, 27 de dezembro de 2010.
} 
Esse conjunto de relações traduz uma dinâmica de enfrentamentos e contradições diante da aceitação, ou não, da possível idealização de uma "identidade metalúrgica" e das mudanças que se colocam nas relações de trabalho de modo mais amplo. Por isso, nos caminhos produzidos por determinados trabalhadores, a relação com a Krupp foi efetiva e intensa, mas não a primeira nem a única a se articular na rede de trabalhos e expectativas, embora tenha sido marcante para trabalhadores e para os pesquisadores que se propuserem interpretá-la.

Por tudo isso, cabe discordar com parte das declarações de Hobsbawm (2000), para alinhavar alguns encaminhamentos finais sobre a posição aqui assumida no debate e no reconhecimento dos trabalhadores como sujeitos atuantes na transformação da realidade social.

Corremos o perigo de esquecer que o sujeito e o objeto de nossas pesquisas são os seres humanos? Não deveríamos correr este risco, pois são as pessoas - não o "trabalho", mas os homens e mulheres trabalhadores reais, mesmo que frequentemente ignorantes, míopes e preconceituosos - o que nosso estudo focaliza. Para muitos de nós o objetivo final de nosso trabalho é criar um mundo no qual os trabalhadores possam fazer sua própria vida e sua própria história, ao invés de recebê-las prontas de terceiros, mesmo dos acadêmicos (HOBSBAWM, 2000, p. 30).

O autor, ao retomar produções e compreensões que versam sobre a "história operária", destacou o "risco" de a reflexão sobre o "trabalho" ficar à frente das atuações dos trabalhadores, considerando necessário que tenhamos maior clareza nas intervenções que realizamos, refletindo sobre onde e como situamos esses sujeitos nas relações e no processo histórico. Contudo, se num primeiro momento sua fala merece esse enaltecimento, encerra-se aí sua contribuição na potência dos "trabalhadores reais", pois as brechas que desconstroem o encaminhamento anterior aparecem nas reticências sobre a consciência e as mudanças de sujeitos "frequentemente ignorantes, míopes e preconceituosos".

Na reavaliação de suas próprias construções acadêmicas, sobre o papel dos trabalhadores na transformação da sociedade, o apreço pela formação e dirigismo sobre essa classe não lhe permite - ainda que o incômodo da noção "trabalho" suprimir o sujeito "trabalhador"o motivasse a fazer tal análise - que sua última inflexão não tivesse a 
força que possivelmente quis acentuar. Ao sugerir que "os trabalhadores possam fazer sua própria história”, a frase de efeito não tem consistência política. Além de coragem e condescendência em pronunciá-la, é necessário reconhecer as práticas de trabalhadores como caminhos possíveis para produzir e confrontar alternativas históricas, mesmo que elas possam nos desagradar.

Neste sentido, os desagrados precisam ser encarados como tais, e não desqualificados como ignorância ou superstição. Os caminhos estão sendo traçados e confrontados na agenda de urgências e projetos desses sujeitos; resta saber que posicionamento estamos dispostos a tomar em nossa pauta de atuação.

\section{Referências}

HOBSBAWM, Eric. História operária e ideologia. In: . Mundos do Trabalho. Novos estudos sobre história operária. 3. ed. Rio de Janeiro: Paz e Terra, 2000. p. 15-31.

KISHIDA, Marino; SILVA, Adriano H.; GUERRA, Ezequiel. Benefícios da Implementação do Trabalho Padronizado na ThyssenKrupp. 2006. Disponível em:

http://www.lean.org.br/comunidade/artigos/pdf/artigo_95.pdf Acesso em: set. 2011

MARQUES, Juliano R. Jundiaí, um impasse regional. O papel de Jundiaí entre duas regiões metropolitanas: Campinas e São Paulo. 2008.178 fl. Dissertação (Mestrado em Geografia) - Programa de Pós-Graduação em Geografia Humana - Universidade de São Paulo São Paulo.

MARX, Karl. O Capital. São Paulo: Abril Cultural, v. I, Tomo I, 1983.

NEGRO, Antônio L. Servos do Tempo. In: ARBIX, Glauco; ZILBOVICIUS, Mauro. De JK a FHC. A reinvenção dos carros. São Paulo: Scritta, 1997, p. 89-131.

TELLES, Vera da S. Mutações do trabalho e experiência urbana. In: Tempo Social, São Paulo, v. 18, n.1, 2006. p. 173-195.

THYSSENKRUPP Metalúrgica Campo Limpo celebrando seus 50 anos. Disponível em: http://www.thyssenkrupp-forginggroup.com/language-pt/news/2011 july.htm Acesso em: ago. 2011. 
No forjar das possibilidades: a "Krupp" Campo Limpo Paulista nos caminhos de trabalhadores

(Segunda metade do séc. XX e início do séc. XXI)

Recebido em: 02/10/2012 Aprovado em: 01/04/2013

Universidade do Estado de Santa Catarina - UDESC Programa de Pós-Graduação em História - PPGH Revista Tempo e Argumento Volume 05 - Número 09 - Ano 2013 tempoeargumento@gmail.com 